\title{
Tourism Destination Management in Creating the Local Community Welfare
}

\author{
Ida Ayu Putu Widiati, Luh Putu Suryani, Ketut Adi Wirawan \\ Faculty of Law \\ Universitas Warmadewa \\ Denpasar-Bali, Indonesia \\ widiati_dayu@yahoo.co.id
}

\begin{abstract}
Bali is one of the tourism destinations. Tourism should provide positive impacts on the social, economic and cultural development of the society around the tourist destinations. This study aims at identifying the model of management of tourism destinations resulting in the welfare of local communities. The study used a conceptual and statutory approach to legislation to analyze the ideal model of management of tourism destinations in Bali. In the theoretical level, the method used is normative juridical which is presented descriptively. The results show that tourism destination management model is to increase the location of tourist attraction by forming a culture-based tourist village. In this concept, the community can arrive at the planning stage so that the characteristics of a village; the potential, needs and capacities of the community to recognize; a delegation of power or partnerships can be realized by making agreements (two-sided public acts) between local government and local community or customary society on the management of tourism destinations that are partially or entirely entrusted to local communities. Efforts to maximize community involvement in tourism management will create synergy and transparency of tourism destination management so that people's welfare can be realized.
\end{abstract}

Keywords-authority; management; tourism destination; local community

\section{INTRODUCTION}

Tourism in Indonesia is increasing rapidly in line with the rapid rate of development of information and technology. The rapid growth of Indonesian tourism has implications for the economy of large foreign exchange for the country. To create sustainable tourism, an integrated effort among sectors to manage all the supporters of tourism activities in Indonesia is required. One of the supporters of tourism in Indonesia is a tourist attraction in tourism destinations. The tourist attraction is turned on by the community as a form of change and social interaction. The public also needs to obtain a strategic position in the field of tourism business in Indonesia. Various existing and existing tourist attraction must be planned maturely by not ruling out the position of the community as one of the stakeholders in the tourism sector. In Bali, in particular, the tourism sector is potentially the most promising sector in bringing in foreign exchange. Even in 2017 Bali became the largest foreign exchange contributor in the tourism sector. Appropriately, the euphoria of tourism in Bali is balanced by strategic and planned efforts to maintain the sustainability of tourist attractions and the welfare of local communities.

Ningsih [1] revealed that Pakraman village plays a very important role in the development of tourist village because it has the potential and ability in developing a tourist village in Tenganan Pegringsingan Village so it continuously grows until today. In addition, the development of tourist villages in the Village Tenganan Pegringsingan provide a great contribution for the community tourism business either in the form of business opportunities and can increase community income. In contrast with this evidence, Jupir [2] claims that the vocation of tourism based on local wisdom, from the economic side, has not contributed optimally to government, private and public. Furthermore, Wahyudi [3] synthesizes that policies of tourism industry development and job creation and poverty alleviation have not fully prospered the community but otherwise poverty is still found in the rate that many have an impact on poverty alleviation. The three writings focus on the role of tourism to the welfare of local communities, but have not discussed the model of management of tourism destinations in an effort to prosper the local community. Departed from the above mentioned evidence, in this paper the ideal model to be applied as a unified strategic government policy toward tourism management in Bali is studied. Government policy in the field of management of tourism destinations aims to prosper the lives of local communities in the vicinity of tourism destinations.

\section{METHOD}

To obtain the results as in the form of the objectives of this paper, the design of normative juridical research to produce policy models in the management of tourism destinations resulting in the welfare of local communities is utilized. The approaches used are the conceptual approach and the approach of legislation to the law. The legal material relating to tourism and its acquired management is processed and analyzed using legal theory. The results of data analysis are presented qualitatively descriptive. 


\section{RESULT AND DISCUSSION}

\section{A. Basic Relation of National Tourism Implementation to Community Purposes}

The sustainability of tourism dynamic is inevitable. Given in the concept of tourism in Law No. 10 of 2009 [4], through the system approach it can be seen that there are many parties as elements arranged in a systematic and interconnected in their respective activities form a global activity called Tourism. The parties that act as the driving force of tourism are the society, the Government, and the Regional Government. Building on it, in order that tourism in line with the spirit of national development can be organized properly, the role of the parties is interconnected with each other in an integrated and sustainable in tourism activities is necessary.

In the concept of tourism in Law no. 10 of 2009, through system approach, there are many parties that are interconnected in a global activity called Tourism. The parties as the driving force of tourism among others community, Government, and Local Government. In order for tourism to be in line with the spirit of national development, the role of the parties interconnected with each other in an integrated and sustainable manner is required.

The government plays a dominant role in the field of tourism policy. Ida Bagus Wyasa Putra [5] Disclose the form of tourism policy arrangement which includes the following matters:

- "Implementation of concepts, principles, requirements, economic technical standards, trade, service trade, and especially trade in tourism services in Indonesia's tourism activities;

- Identification of relationship, form, requirement, treatment and obligation of tourism business actors, in the form of cultural and social responsibility, to the culture and its supporting community;

- The legal policy governing it [5]."

The scope of policy of tourism which is the responsibility of the government puts the government itself, both central government and local government in a position as a determinant of orientation (holder of orientation) in the implementation of tourism activities. Central and local governments develop legal policies to ensure the sustainability of sustainable tourism by considering the elements mentioned in points 1 and 2 .

Legal policies on tourism should be integrated with other sector legal policies, so directing tourism policies that refer to national legal policies play an important role. With an understanding of the legal thinking of "legal theory of development", a construction of legal standing in the development of a developing country like Indonesia is obtained. This thinking tends to lead to a legal political dimension that places law as a subordination of the ideology of development itself [6]. In line with this view, national legal policy becomes a systematic part of national development policy, and the orientation of tourism policy is inseparable to the orientation of national development policy.
The national development orientation is set forth in Law Number 25 of 2004 on National Development Planning System. In Article 1 point 2 explained that "National Development is an effort implemented by all components of the nation in order to achieve the goals of the state". If traced more broadly, the purpose of the state as the fourth paragraph in the Preamble of the Constitution of the Republic of Indonesia is the social welfare of the community through protection, enhancement of human resources, and carrying out foreign policy all based on the noble value of Pancasila. The purpose of the State in the political configuration is manifested in several stages as exposed in the explanation of Law No. 25 of 2004, namely: (1) the preparation of the plan; (2) the determination of the plan; (3) controlling the implementation of the plan; and (4) evaluation of the implementation of the plan. The four stages are held on an ongoing basis so as to form a whole planning cycle. Furthermore, still in the explanation of Law No. 25 Year 2004, written a plan of the plan to be a legal product so that all parties are banded to implement it.

The illustration of the law is not a part of the norm, but can be used as the first reference in an attempt to interpret the essence of a norm. Thus, the legal position in the national development policy can be termed as "means" in realizing the goals of the state. Referring to the national development objectives, the various fields in the life of the state including tourism are directed to the national development objectives. It is undeniable that the law occupies a central position in determining the policy of tourism activities in Indonesia. As a derivative of Law No. 10 of 2009, tourism policy orientation in Government Regulation of Republic of Indonesia Number 50 of 2011 on Master Plan of National Tourism Development Year 2010-2025 (Government Regulation No. 50 of 2011) has been imposed. In Article 2 paragraph (1) of Government Regulation 50 of 2011 stated that in realizing the vision of national tourism development as intended in paragraph (4) taken through 4 (four) national tourism development mission which includes the development of tourism destinations, tourism marketing, tourism industry and tourism institutions. Tourism institutions encompass the Governmental Organization, Local Government, private and community, human resources, regulations, and effective and efficient operational mechanisms. (The underline of the authors).

Society is one component supporting the implementation of national tourism. From this essence logical concepts can be established, such as tourism is supported by several supporting elements, such as tourism destinations. In tourist destinations there is a tourist attraction. The tourist attraction of Indonesia can take the form of natural wealth, culture, and objects of man-made products. The three forms of tourist attraction place the human being as the center (central) driving the tourist attraction. Humans referred to are humans who reside in the vicinity of tourist destinations. By viewing from a sociological perspective, the collection of humans living together and interacting with each other or interacting with their environment (being social beings) is called society [7]. In the context of tourism destination, there is no clear regulation of which people are called a community. If interpreted, the community referred to is the community in the vicinity of 
tourist destinations that are directly related to tourism activities at the location of the tourist attraction itself.

Individuals in society naturally engage in interactions called social interactions because of various motivation/encouragement. Different interest drives create different actions. But instinctively human beings who interact in society are driven by interests to gain happiness or prosperity. Therefore, the common goal which is the goal of society is prosperity. Obviously this goal is in line with the purpose of the state as described in the previous section, so that the implementation of national tourism as much as possible can be directed aligned to the public interest (community goal). Any form of tourism policy should not deny the common objectives as well as the objectives of society because the true dimensions of the axiology of society lead to a strong and fundamental relationship with the goal of national tourism.

\section{B. Construction of Tourism Destination Management to Create Local Community Welfare}

Through the authority of attribution under Law no. 23 of 2014 , local governments have full authority in the management of tourism destinations embodied in the form of legal policy in the field of tourism. Based on this, the Bali Provincial Government established Bali Regional Regulation (Perda) No. 12 of 2012. Article 11 of the Perda contains the following provisions:

- Local wisdom such as the beliefs of the Balinese people based on Tri Hita Karana and imbued by Hinduism;

- Cultural and environmental sustainability, such as traditions, Balinese customs, and environmental rules;

- The economic potential of the community such as providing opportunities to local businesses in both handicrafts and agricultural products to showcase their works in hotels, restaurants and other tourist attractions; and tourism business sustainability.

There are various strategies in the development of Bali tourism destination that are done by putting a central point in community. Local wisdom, culture and environment as well as the economic potential of the community is a categorization of attention in which there are communities as the main actors who play a role in all these elements. It is important that all concretization of the policies of the local government of Bali in the development of tourism destinations to open wide access to community participation can be formed. Public participation is necessary given the several points of interest as mentioned above are only clearly known by local communities in the area of tourism destination itself (tourism destinations).

Concepts of 'participation' according to Black's Law Dictionary are: 1). The act of taking part in something; 2) the right of an employee to receive part of business profit [8]. In the Big Indonesian Dictionary, it is described that participation contains understanding about participating in an activity; participation; participation [9] Participation can be interpreted as participating, participating in an activity, from planning to evaluation [10]. Participation of society in the realization of public policy by the government can be categorized as political participation that can be done by the community. Political participation by Huntington and Nelson is defined as the activity of citizens (private citizen) which aims to influence the decision-making by the government [11]. It was revealed by Hamzah that there are some concepts of participation, namely:

- Participation as policy. This concept views participation as a consultation procedure of the policy makers to the community as the subject of local regulation.

- Participation as a strategy. This concept sees participation as one of the strategies to gain public support for the credibility of government policy.

- Participation as a communication tool. This concept sees participation as a means of communication for the government (as a servant of the people) or to know the will of the people.

- Participation as a means of dispute resolution [10].

Participatory method (community participation) is needed in a series of determination of tourism management policy, especially management of tourism destinations. Article 1 Number 41 of Law 23 of 2014 states "Community Participation is the participation of citizens to channel their aspirations, thoughts and interests in the implementation of Regional Government."

Sherry Arnstein in Sirajuddin argues that there are eight levels of public participation in deciding policy, among others: 1). Community control (citizen control); 2). Delegated power; 3). Partnerships (partnership); 4). Placation; 5). Consultation; 6). Informing; 7). Therapy (therapy) and 8). Manipulation (manipulation) [11]. If is comprehended the eight (8) types of community participation models share different effectiveness in influencing government policy in determining a decision in the realm of public law. Furthermore Sirajuddin classifies 8 types of levels of participation into 3 different levels. Points 13 are classified into degree of citizen power, 4-6 are classified into Degree of Tokenism, 7 and 8 are classified into non participation levels. Hence, the ideal form of participation of local communities in the management of tourism destinations in the form of community control, power delegations or partnerships [11].

Concretely the three forms of local community participation in the management of tourism destinations mentioned above can be realized through the following things: First, the tourist attraction by forming a culture-based tourist village. In this method the local government plays a dominant role, then the control of society can enter at the planning stage. In the planning stage can be known characteristics of a village, potential, needs and capabilities of the community. That the development of culture-based tourist villages in Bali is not a "boomerang" to the cultural existence of local communities or even narrow the economic access of local people in the tourism sector. Second, the delegation of powers or partnerships can be realized by making agreements (two-sided public acts) between the local government and local community or indigenous community officials on tourism management. The agreement (second-order public action) means that the management authority of a tourism destination is left partially (with a profit- 
sharing system) or entirely is for local community or indigenous people, with which local governments assist in the procurement of structures and infrastructure as well as oversight. This method is even more effective where the community and government as stakeholders to the implementation of tourism, get a balanced benefit from the implementation of tourism in tourist destinations in the region.

The idea of development of tourism destinations in the Province of Bali is in line with the orientation of development of tourism destinations in Bali Province Regulation No. 10 of 2015 on Master Plan of Regional Development of Bali Province 2015-2029. In Article 13 of Bali Regional Regulation No. 10 of 2015 stipulated that the development of regional tourism destinations as referred to Article 2 paragraph (1) part a, including: a. territorial tourism destinations; b. development of Tourism Attractions; c. development of tourism accessibility; d. construction of public infrastructure, public facilities and tourism facilities; e. community empowerment through tourism; and f. development of tourism investment. May the two ideas of tourism destination management mentioned above can be in line with the orientation of tourism destination development of Bali Province 2015-2029. Providing opportunities for the community to be actively involved in the management of tourism destinations in line with the ideals to realize the welfare of local communities in tourism destination through tourism sector.

\section{CONCLUSION}

The main objective of the implementation of national tourism that is for tourism directed in harmony with the public interest in order to realize the welfare of society. The implementation of national tourism includes management of tourism destinations that are the authority of local government attribution. Based on the authority, the Bali Provincial Government established Bali Regional Regulation no. 2 of 2012 on Balinese Culture Tourism. Moving from the principles and objectives of the regional regulation, the idea of tourism destination development model is as follows: First, increase the location of tourist attraction by forming a culture-based tourism village. In this method the local government plays a dominant role, then the control of society can enter at the planning stage. In the planning stage can be known characteristics of a village, potential, needs and capabilities of the community. Second, the delegation of powers or partnerships can be realized by making agreements (two-sided public acts) between the local government and local community or indigenous community officials on tourism management. The agreement (second-order public action) means that the management authority of a tourism destination is left partially (with a profit-sharing system) or entirely is for local community or indigenous people, in which local governments assist in the procurement of structures and infrastructure as well as oversight.

\section{ACKNOWLEDGEMENT}

The author would like to thank all the parties who have helped and contributed in the writing of this article, both those who contribute in the form of funding and critical ideas. Hopefully this paper can be useful theoretically and practically for the addition and development of knowledge, especially in the field of legal science.

\section{REFERENCES}

[1] Ningsih, Ni Wayan Ratna Sriwijaya. "Peranan Desa Pakraman dalam Pengembangan Desa Wisata di Desa Tenganan Pegringsingan Kecamatan Manggis Kabupaten Karangasem." Jurnal Pendidikan Geografi Undiksha 3.1, 2013.

[2] Jupir, Maksimilianus M. "Implementasi kebijakan pariwisata berbasis kearifan lokal (Studi di Kabupaten Manggarai Barat)." Journal of Indonesian Tourism and Development Studies 1.1, 2013: 28-38.

[3] Wahyudi, Hery. "Pariwisata, Pengentasan Kemiskinan dan MDGs." 2012.

[4] Law No. 10 Year 2009 on Tourism

[5] Putra, I. B. W., Hukum Bisnis Pariwisata, PT. Refika Aditama, Bandung, 2003,

[6] Sidharta, M. K., Atmadja dan Teori Hukum Pembangunan: Eksistensi dan Implikasi, Epistema Institute, Jakarta, 2012.

[7] Soedjono, Sosiologi, Penerbit Alumni, Bandung, 1982.

[8] Garner, B. A., Black's Law Dictionary, Ninth Edition, West Publishing, USA, 1999.

[9] Sugono, Dendy, Kamus Bahasa Indonesia , Pusat Bahasa, Jakarta. 2008.

[10] H. Hamzah, Cara Praktis Menyusun Dan Merancang Peraturan Daerah (Suatu Kajian Teoritis Dan Praktis Disertai Manual): Konsepsi Teoritis Menuju Artikulasi Empiris, Kencana Prenada Media Group, Jakarta. 2009 ,

[11] Sirajuddin, Legislatif Drafting: Pelembagaan Metode Partisipatif Dalam Pembentukan Peraturan Perundang-Undangan, Setara Press, Malang. 2015 . 